\title{
Analysis Performance of Grid Tie Photovoltaic Type Polycrystalline Using Solar Irradiance Simulation.
}

\author{
Kurniawan Galih Putra Pratama ${ }^{1,{ }^{*}}$,Hermawan Hermawan ${ }^{2}$, and Trias Andromeda ${ }^{2}$ \\ ${ }^{1}$ Magister Study Program of Electrical Engineering, Diponegoro University, Semarang - Indonesia \\ ${ }^{2}$ Department of Electrical Engineering, Faculty of Engineering, Diponegoro University, Semarang - Indonesia
}

\begin{abstract}
Indonesia is a country consisting of several islands some of which are still not covered by electricity. It is this source of PV that can be used to meet the needs of people who are not yet affordable with PLN electricity. Basically, PV includes the generation of new renewable energy types. This new form of energy comes from sunlight. Using semiconductor materials can convert energy from sunlight to electrical energy. Because in Indonesia this includes tropical climates located on the equator line, making Indonesia has a very high intensity of light. Several factors affect electrical energy, namely the extent of PV to be used, the total irradiance received by PV, the decrease in performance due to weather and cleanliness of the PV used such as snow and oiliness. In this study explained the Analysis of Irradian-based Grid Tie photovoltaic performance with Polycrystalline PV types. Taking irradian data using a Solar Power Meter, irradiance and temperature data at a certain time will use the Incremental Maximum Power Point Tracking (MPPT) method, DC-DC boost converter, inverter, voltage source converter (VSC) using algorithm and equipment controls connected to network. This research is simulated using Matlab with the Simulink program.
\end{abstract}

Keywords: Grid, Irradiance; Temperature; Solar Photovoltaic; PVArray; MPPT.

\section{Introduction}

In the era of the 90s electricity, technology was still largely sourced from fossil fuels. However, with the increasingly advanced era of fossil fuels, alternatives have been sought due to having a limited amount of earth. One search for research and research is to look for forms of energy that are safe for the environment and have unlimited resources. One form of renewable energy sources, namely the sun. Because the sun is considered to be an energy source that will not run out and is friendly to the environment on earth. The transformation from being to electricity is by using the source of sunlight which shines on the semiconductor material then there is a transfer of energy in it to produce electricity. Photovoltaic is a technology that reliably converts solar radiation into electricity. There are various types of modules depending on power ratings. Each module has a number of solar cells. Solar cells are made with conductor conductors such as silicon. Photovoltaic cells produce electricity in a clean and reliable way which is a major problem for the environment today. Temperature variations greatly affect the efficiency of solar modules.

Photovoltaic (PV) power systems Currently experiencing developments from small systems to systems connected to large networks [1]. The connection of this system brings an era of new dimensions to renewable energy technology. With many advantages, this system can leave the boundaries of the old energy source system sourced from conventional fuels. Even now the government is starting to push this system into the household industry. There are various forms of development, for example, the installation of solar power plants on the roofs of buildings which are now regulated in the ESDM PERMEN No. 49 of 2018 [2].

\section{Photovoltaic Cell}

Photoelectric or photovoltaic is a semiconductor material. photovoltaic absorbs sunlight and generates a charge and converts it into electrical energy. The working principle of PV solar cells that are exposed to solar radiation with certain values makes electrons move places. The displacement of these electrons produces a current. This current will later be used as a source of electrical energy. Solar Panels use the main components, namely silicon. Each solar panel has special characteristics. The difference is in the purity of silicon. The more pure silicon is used in PV, the better the solar cells will convert solar energy into sunlight. Assembling silicon on PV has various forms namely Monocrystalline and 
Polycrystalline. These two solar panels have similarities in terms of price and performance.

Monocrystalline solar panels. The type of monocrystalline solar panel is made with silicon which is made into bars and sliced. The shape of the silicon cuttings in monocrystalline PV is singular. Because cells are made from a single crystal, the electrons that produce electricity have more space to produce. Polycrystalline solar panelsPolycrystalline solar panels in PV are the same as the monocrystlline type which is made of silicon. However, pieces of silicon are different. In the Polycrystalline type, silicon does not form singly on melting so that it becomes a slice for the panel. Polycrystalline solar panels are also called multi-crystals or many silicon crystals. PV work systems that use sunlight to illuminate solar panels that are needed by electron transmission, this transfer produces electricity.

The characteristic of sunlight radiation is that the wavelength $(\lambda)$ is inversely proportional to the photon energy (E); where $\mathrm{c}=$ velocity of light, $\mathrm{h}=$ Planck's constant [3].

$E=h c / \lambda$

\subsection{Solar Irradiance}

Solar irradiation is the level of sun exposure on a surface. It is usually expressed in $\mathrm{W} / \mathrm{m}^{2}$. Radiant power is the rate of flow of electromagnetic energy. Exposure to sunlight will be used to produce electromagnetic energy flow rates.

Electromagnetic waves come from photon energy at different energies, which move at a constant speed. Light from the sun has a spectrum that coincides with a black line at a temperature of $5762 \mathrm{~K}$. The dashed line shows radiation of black matter that works at this temperature. In the figure mentioned (AM) 0 , this corresponds to the notion that the spectrum outside the Earth's atmosphere is in a plane perpendicular to the sun at an average distance of the earth to the sun. AM 0 outside the Earth's atmosphere is $1367 \mathrm{~W} / \mathrm{m} 2$ and this is known as the solar constant.

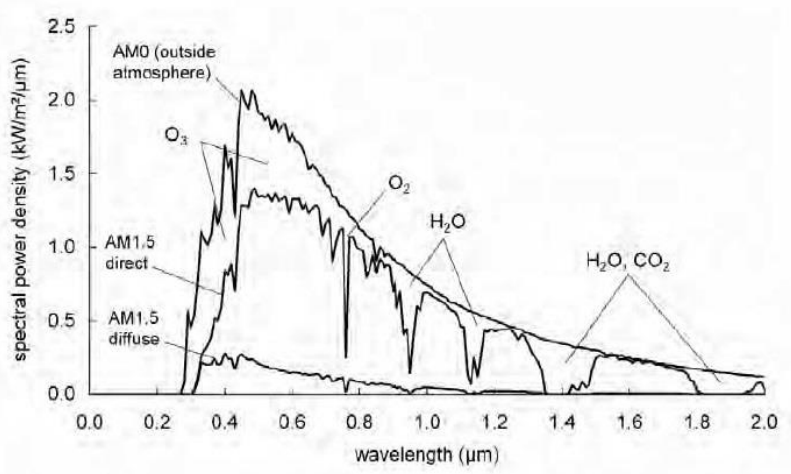

Fig. 1. Wavelenght model Solar Irradiance [1]
Table 1: Shows weather report as at data collection period [4]

\begin{tabular}{|l|l|}
\hline .Date & Sunday, 26 May 2019 \\
\hline Time & $06: 00-14: 00$ \\
\hline Temperature & $24 / 34{ }^{\circ} \mathrm{C}$ (lowest/highest respectively) \\
\hline Humidity & $56 \%$ \\
\hline Barometer & $1012 / 1009 \mathrm{mbar}$ \\
\hline Wind Speed & $14 \mathrm{~km} / \mathrm{h}$ \\
\hline Source & Courtesy of www.wheather.com \\
\hline
\end{tabular}

\subsection{Modeling of Photovoltaic Module}

Some examples of solar cell modeling are available in the literature. Generally, the model uses two-diodes and there is also one-diode used in the simulation. But using singlediode is more popular because of its simplicity and accuracy. The solar cell modeling series is generally represented by using Thevenin's law or Norton equivalent [11]. The ideal diode model is not connected by series or parallel to the resistance. With barriers connected parallel to the circuit affecting the efficiency of PV modules [1214]. Single-diode circuits such as in the figure have photon current sources, anti-parallel diodes and (series and parallel resistance). There are numbers of equivalent circuit models [5] of solar cell available in literature but Single-diode model is more popular because of its simplicity and accuracy[1], [6]. An equivalent Singlediode circuit of solar cell is shown in Figure 2.

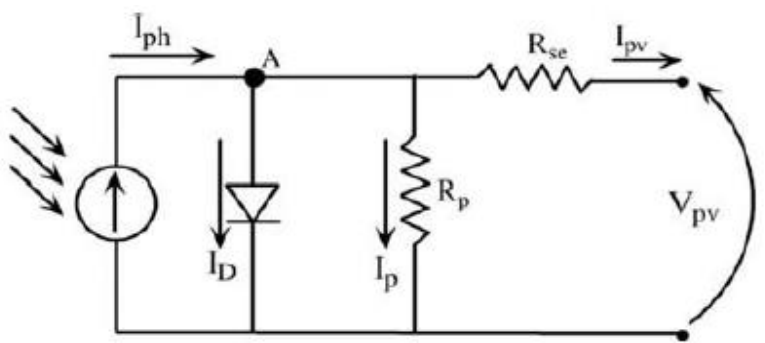

Fig. 2. Equivalent circuit of the single diode model [1].

Kirchhoff's law is applied to node 'A' in Figure 2:

$I_{p v}=I_{p h}-I_{D}-I_{p}$

where ;

IPV is marked PV output

Iph is marked current on PV

Ip is marked current through shunt resistance and ID current of the diode principle can be stated by

Semiconductor theory as [11]:

$I_{D}=I_{O}\left[\exp \left(\frac{q\left(V_{p v}+I_{p v} R_{S}\right)}{A N_{S} K T}\right)-1\right]$

where :

Io is the output current inversely through the diode, Vpv is interpreted as a PV output voltage,

Ns is interpreted as the number of PV cells connecting in series,

Whereas $\mathrm{K}$ as is Boltzmann's constant value

$(1.38 \times 10-23 \mathrm{~J} / \mathrm{K}), \mathrm{A}$ is the ideality factor that depends on the PV cell construction and $\mathrm{T}$ is the cell temperature.

Equation (4) shows the output current for a practical circuit consisting of two resistance [1]: 
$I_{p v}=I_{p h}-I_{O}\left[\exp \left(\frac{q\left(V_{p v}+I_{p v} R_{S}\right)}{A N_{S} K T}\right)-1\right]-\frac{V_{p v}+R_{S} I_{p v}}{R_{p}}$

There are five important parameters connected with the nonlinear Solar Cell Equation above: Flow, saturation current, ideality factor, series resistance and parallel resistance in describing the equation of solar cells, solar radiation and surrounding temperature indirectly describe the value of the solar cell produced. Each manufacturer of solar panels manufactures experiments such as opencircuit voltage, short circuit current, and maximum point detection, the amount of current in PV during Standard Test Conditions (STC). There is a difference when the system is run with when the STC condition. So the values obtained from these five parameters make an important role in the basis of the formation of PV arrays.

\subsection{Effect of Temperature and Insolation on PV System}

Solar Panel system output is based on Irradiance and temperature are the two main factors [7]. The increase in insulation (solar intensity) due to the temperature of solar cells rises or is caused due to energy loss in the photovoltaic process. Rising temperatures cause the output of the PV system to decrease. The increase in temperature also affects the Voc of the PV system to decrease. Because the temperature decreases, as a result, the IPv of the PV system rises. Changes in temperature and radiation ultimately change the value of the output voltage and current. In modeling PV the effects of temperature and radiation become important must be taken into account. The following equation becomes the Characteristics of $\mathrm{PV}$.

$I_{s c}=I_{s c, r e f}\left[1+\alpha\left(T-T_{\text {ref }}\right)\right] \frac{G}{G_{\text {ref }}}$

$V_{o c}=V_{o c, r e f}\left[1+\alpha \ln \frac{G}{G_{\text {ref }}}+\beta\left(T-T_{\text {ref }}\right)\right]$

where :

$\alpha$ and $\beta$ are expressed as temperature coefficients $\mathrm{G}$ and Gref are solar radiation and its parameter values $\mathrm{T}$ and Tref are the temperature of the solar cell and have parameter values and a is a radiation correction factor

\subsection{Maximum Power Point Tracking (MPPT) Algorithms}

In the use of a PV performance system, identify which point is best for getting the most effective results when operating on the output system. Changes in temperature and radiation in the MPPT method are needed to find and maintain peak power. This method aims to determine the voltage or current where the PV system provides the maximum output power. The MPPT method is generated and designed from a variety of control systems, and variable control, performance, and cost. Basically, the MPPT algorithm here focuses on additional conductance methods.

\subsection{DC-DC Boost Converter}

DC-DC boost converter is used to maximize the PV output voltage on the desired working system. There are two important tasks the addition of this converter is that of connecting PV or a renewable source with the MPP detection grid. On the I-V curve with the help of the MPPT control algorithm. Capacitors and Inductors function as voltage wave filters that have switching patterns. In using the DC-DC converter mode, at least one has a power switch with capacitors and inductors. The boost Vo output converter voltage is given as: [10]

$V_{o}=\frac{V_{S}}{1-D}$

where $D$ is the duty cycle $V_{s}$ is the source Voltage

\subsection{Inverter}

The modulation scheme is a working operation of the inverter so that the output varies between positive and negative DC voltage values. Switching the system periodically will create an average output value, which is proportional to sinusoidal AC waves. Because the output from the inverter is not pure sine wave, filters such as capacitors and inductors will be needed at the output terminals to filter out foreign frequency content.

\subsection{Controller}

On equipment connected to the Grid, in particular, uses a 3 phase work system, it is recommended to reduce voltage variations and voltage imbalances. To suppress voltage variations based on the voltage at the inverter terminal, the error reference vector is created as a special control strategy applied to the inverter. The reference is then distributed to the controller to change the reference voltage instantly which causes a change in voltage and voltage fluctuations. With a combination of predictive control and variable structure control, the resulting output becomes better and more effective, but the level of complexity is high and the burden is the main obstacle to this kind of strategy.

\subsection{Grid}

In PV systems that are connected to the load can be connected to the utility network. However, the connection to the network is required to follow the standardization by the utility network. When interruption occurs the instability of the power plant system must remain connected to the network system during the interruption. Other generators can supply voltage by injecting reactive power. When needed. This method is referred to as faultride-through (FRT) [17]. When abnormal frequency conditions occur require active power control for handling. High Penetration of Generators Connected to photovoltaics (GCPV) requires good control techniques to achieve network stability. Static generation is also needed to set Reactive Power Control, Active Power Control, and Dynamic Power Control.

\section{Simulation, Result, and Analysis}


In the application of this case study use the MATLAB and SIMULINK application to analyze it. Irradian data that we get from sunlight measurements using the Power irradiance meter. The results of direct measurement data from sunlight are combined with the measurement data of the current temperature obtained from www.wheater.com. This weather data is transformed into a signal and is used as input to the PV model system that is connected to the network. PV Array provides Active Power WITH Maximum Power Point tracking technique assistance. The PV output voltage increases with a DCDC base boost converter to get network voltage requirements. DC external control loop control system and DC internal control which are active and reactive power components. A three-phase bridge inverter is used to convert DC power to $50 \mathrm{~Hz}$ AC power. Three-phase series capacitor banks are applied to harmonic filter in the model. This AC power output passes through the step-up transformer and then to the network.

Table 2. Basic Simulation parameters for proposed system

\begin{tabular}{|l|l|}
\hline Parameter & Value \\
\hline PV array (5*80) & $400 \mathrm{~W}$ \\
\hline Boost Converter frequency & $5 \mathrm{KHz}$ \\
\hline DC link Capacitors(2) & Cdc $12000 \mu \mathrm{F}$ \\
\hline Ts Conttrol & $12000 \mu \mathrm{s}$ \\
\hline Ts Power & $1 \mu \mathrm{s}$ \\
\hline Descrete Time & $1 \mu \mathrm{s}$ \\
\hline DC reference voltage & $500 \mathrm{~V}$ \\
\hline 3 level 3-phase VSC & $1650 \mathrm{~Hz}$ \\
\hline 3 Level bridge Inverter & $3 \mathrm{arms}$ \\
\hline PV to Grid Transformer(Step Up) & $100 \mathrm{KVA}(260 \mathrm{~V} / 25 \mathrm{KV})$ \\
\hline Capacitive Reactive Power & $12 \mathrm{KVAR}$ \\
\hline Line inductance, & $0.25 \mathrm{mH}$ \\
\hline Line resistance, & $1,885 \mathrm{mOhms}$ \\
\hline
\end{tabular}

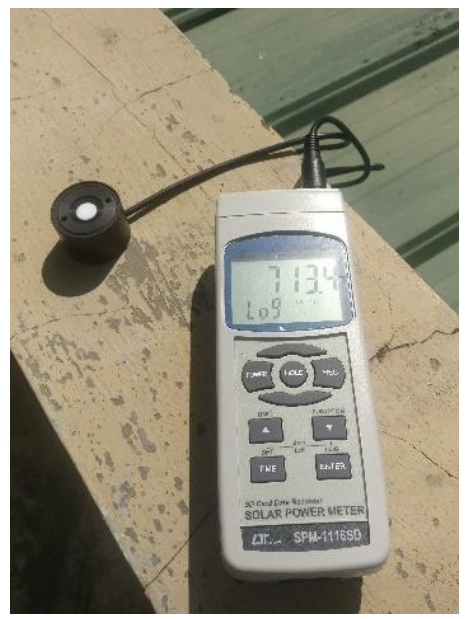

Fig. 3. Shows solar irradiance data being recorded at time interval of one second.

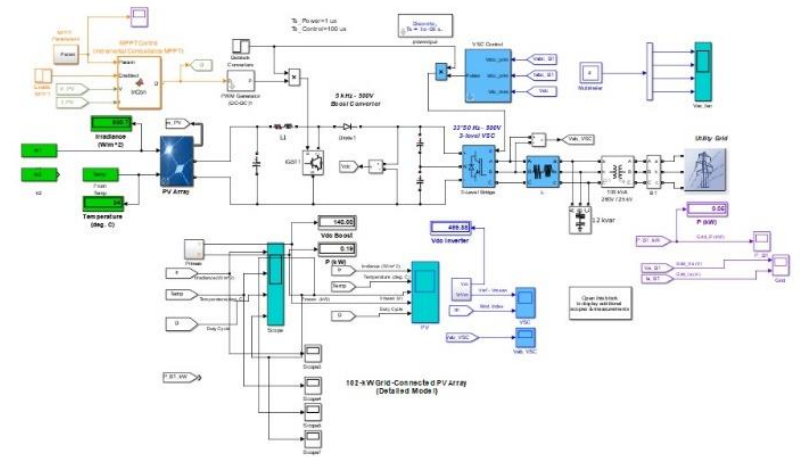

Fig. 4. An overview diagram of a grid-connected PV array model

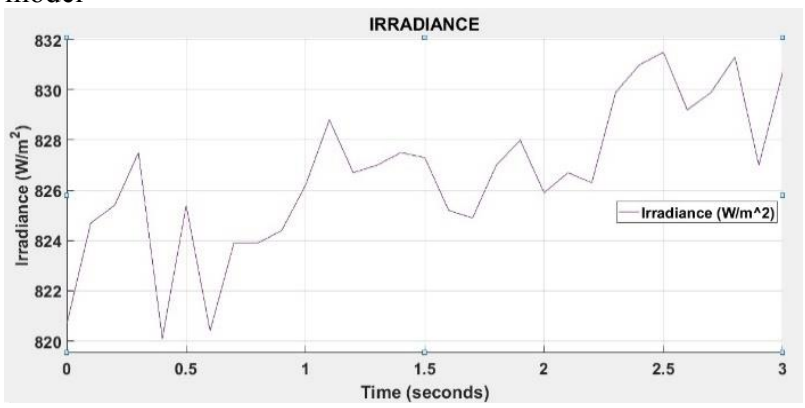

Fig. 5. Data Irradiance Graph

\subsection{Results}

The results of the simulation model are presented below. Detailed discussion of results is presented in sub-section analysis.

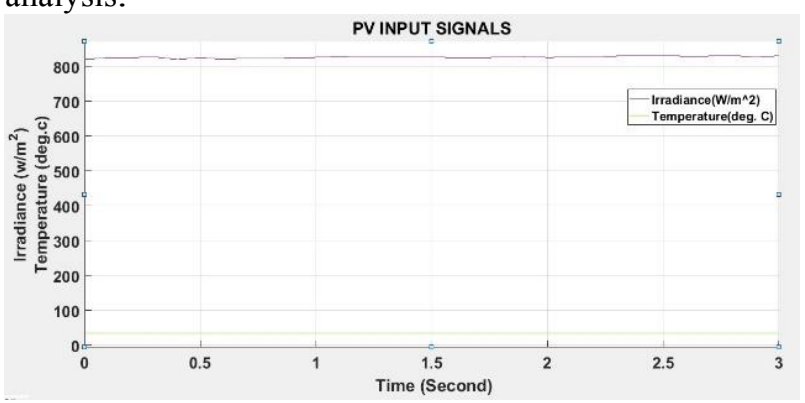

(a)

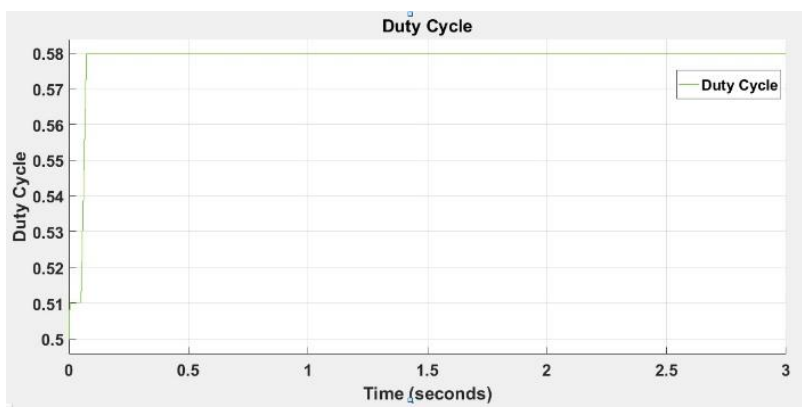

(b) 


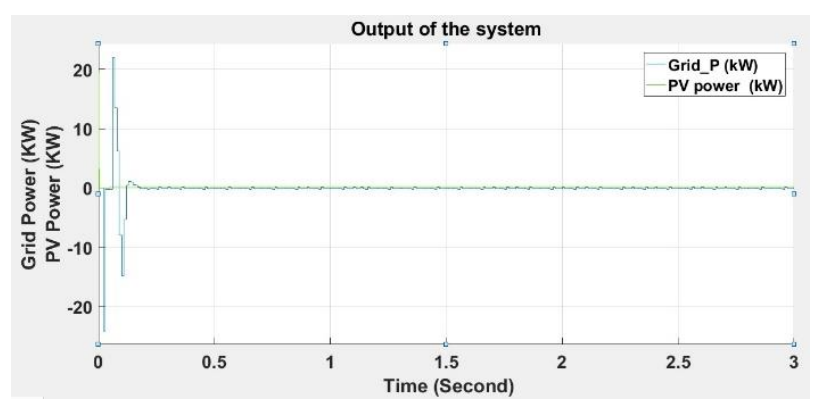

(c)

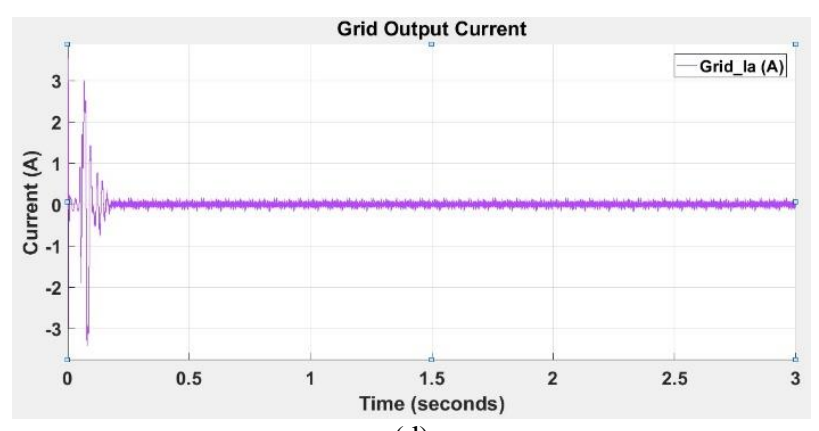

(d)

Fig. 6. Solar Irradiance data waveform (a) PV input signals, (b) duty cycle, (c). PV and inverter output power and (d) grid output current.

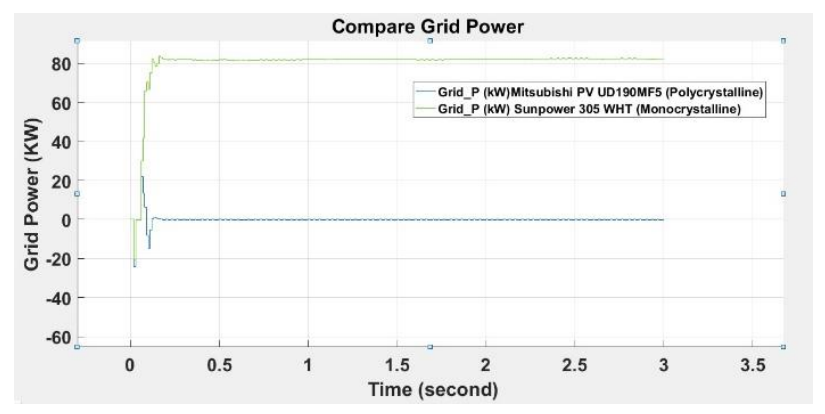

(a)

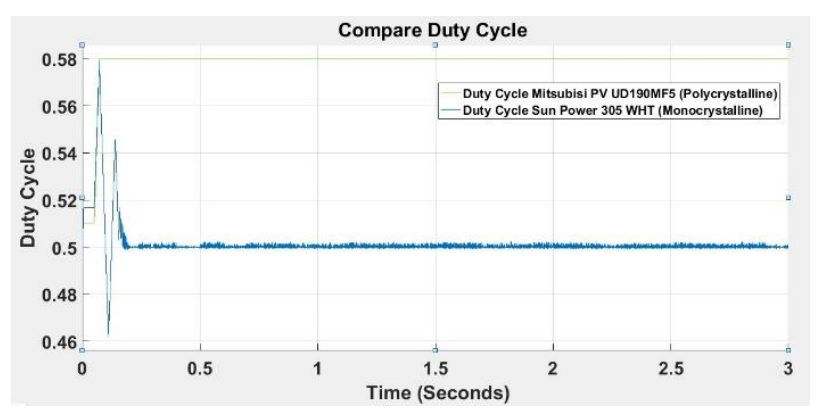

(b)

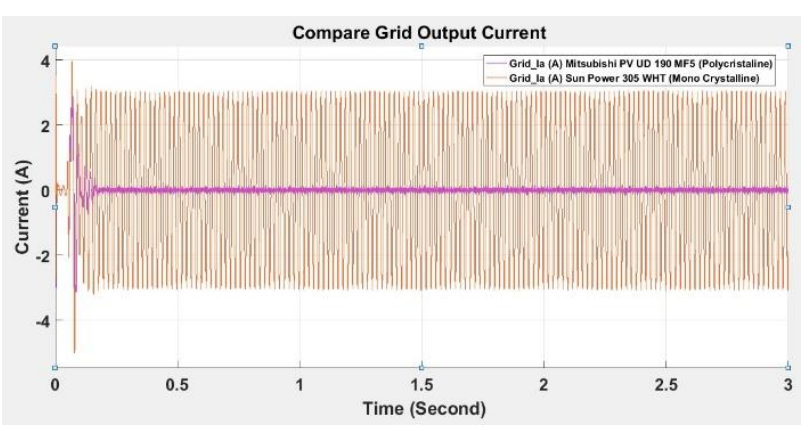

(c)

Fig. 7. Peak Solar irradiance data with moderate deviation range (a) Compare Grid Power (b) Compare duty cycle (c). Compare grid output current.

\subsection{Analysis}

From the reference Figure 5 Simulation from the Irradian data that I can have the highest value Irr: $831.5 \mathrm{~W} / \mathrm{m} 2$ and has the lowest value $820.1 \mathrm{~W} / \mathrm{m} 2$. This measurement was categorized as good because at the time of the measurement it was sunny so that Solar Irradiance sensors could measure and identify the magnitude of irradiation properly. When irradiation measurements are carried out at an average temperature of $34{ }^{\circ} \mathrm{C}$. This temperature is used as input from the measurement of this experiment. In Figure 6(a), the results of the comparison of existing Irradian values are compared to the existing temperature and are constant because the irradiation data that I have obtained is not very much so that the graph causes a constant such temperature. In Figure 6(b) the graph of the duty cycle obtained is that the system is stable at 0.58 at $\mathrm{e}$ seconds of 0.08 seconds. Figure 6(c) the comparison of the power output generated by the network and the power produced in PV. There is almost the same value The grid has a graphical value of oscillation output at peak reaching 22 and system stability at 0.24 seconds. Whereas in PV the stability value in the system is 0.2 seconds. In Figure 6 (d) illustrates the current output in the output system the current is stable at 0.17 seconds.

In Figure 6 (e) illustrates the current output in the output system the current is stable at 0.17 seconds. The next discussion shows a comparison of calculations using different types of PV. Calculations using Monocrystalin and Polycrystaline types. Because it has a different type, the results displayed are different. In Figure 7 (a) the Polycrystalline type voltage is only maximal at $22 \mathrm{kw}$ and the system is stable at 0.22 seconds. If the monocrystalin type is emitting power at $82.9 \mathrm{KW}$, and the system is stable at 0.22 seconds. In the comparison of duty cycle Figure 7 (b) both have a peak value that is almost the same, namely 0.58 . However, the monocrystalin system is constant at 0.58 seconds while Monocrystalline is at 0.4 seconds, but the stabilization of Polycrystalline time is faster, which is 0.07 seconds while polycrystalline is at 0.22 seconds. In Figure 3 discusses the comparison of Grid Output output from the two types having the same stability time value which is at 0.19 seconds but the amount of oscillation of the two is different. Oscillation in Monocrsytalilline is in number 3 while in Polycrystalline is in the number 0 . 


\section{Conclusion}

The conclusion obtained from the references after we studied pictures 5 and 6 is the amount of irradiation that greatly affects the output of the system. To achieve the output power of a good system PV must be able to quickly stabilize the system so that it can be reliable and can be immediately entered into the existing network. The type of PV greatly affects the output of the system. Because of each type of PV that exists has characteristics in its system. This validation can be used as a reference for the idea of building a solar power generation system at a potential location.

\section{References}

1. A. Kumar, N. Gupta, and V. Gupta, A Comprehensive Review on Grid-TiedSolar Photovoltaic System, J. Green Eng., 7, 1: 213-254 (2017)

2. Menteri Energi dan Sumber Daya Mineral Republik Indonesia, Penggunaan Sistem Plts Surya Atap Oleh Konsumen Pt. Pln (Persero), Indonesia: Peraturan Menteri Energi Dan Sumber Daya Mineral Republik Indonesia Nomor, P. 18. (2018)

3. Y. T. Tan and D. S. Kirschen, Impact on the power system of a large penetration of photovoltaic generation, 2007 IEEE Power Eng. Soc. Gen. Meet. PES, no. February, (2007)

4. www.wheather.com, "Climate data."

5. A. Durgadevi, S. Arulselvi, and S. P. Natarajan, Photovoltaic modeling and its characteristics, 2011 Int. Conf. Emerg. Trends Electr. Comput. Technol. ICETECT 2011, pp. 469-475 (2011)

6. H. Ibrahim and N. Anani, Variations of PV module parameters with irradiance and temperature, Energy Procedia, 134, 276-285 (2017)

7. H. Bellia, R. Youcef, and M. Fatima, $A$ detailed modeling of photovoltaic module using MATLAB, NRIAG J. Astron. Geophys., 3, 1: 53-61 (2014)

8. S. Narendiran, Grid tie inverter and MPPT - A review, Proc. IEEE Int. Conf. Circuit, Power Comput. Technol. ICCPCT 2013, pp. 564-567, (2013)

9. A. Nasr, A Survey of Maximum PPT techniques of PV Systems, no. May 2012 (2016)

10. Daniel W.Hart, Power Electronics. .

11. R. Dogga and M. K. Pathak, Recent trends in solar $P V$ inverter topologies, Sol. Energy, 183, no. April 2018, pp. 57-73, (2019)

12. A. Soon, T. Tan, D. Ishak, R. Mohd-mokhtar, and S. S. Lee, Grid-Connected PV Generator Using ThreePhase VSC with Model Predictive Control. Springer Singapore.

13. M. P. Kazmierkowski and L. Malesani, Current Control Techniques for Three-Phase Voltage-Source PWM Converters : A Survey, 45, 5: 691-703 (1998)

14. F. Blaabjerg, R. Teodorescu, S. Member, M. Liserre, A. V Timbus, and S. Member, Overview of Control and Grid Synchronization for Distributed Power Generation Systems, 53, 5: 1398-1409 (2006)

15. K. Uchida, Control The Active and Reactive Powers of Three-Phase Grid-Connected Photovoltaic
Inverters Using Feedback Linearization and Fuzzy Logic, no. November, (2013)

16. M. Benchagra and M. Hila, Nonlinear Control of DCbus Voltage and Power for Voltage Source Inverter," 2012.

17. E. Gmbh, New German Grid Codes for Connecting PV Systems to the Medium Voltage Power Grid, pp. $1-4$. 